Bond University

Research Repository

\title{
Comparison of seroprevalence of SARS-CoV-2 infections with cumulative and imputed COVID-19 cases: Systematic review
}

Byambasuren, Oyungerel; Dobler, Claudia C.; Bell, Katy; Rojas, Diana Patricia; Clark, Justin; McLaws, Mary Louise; Glasziou, Paul

Published in:

PLoS One

DOI:

10.1371/journal.pone.0248946

Licence:

CC BY

Link to output in Bond University research repository.

Recommended citation(APA):

Byambasuren, O., Dobler, C. C., Bell, K., Rojas, D. P., Clark, J., McLaws, M. L., \& Glasziou, P. (2021).

Comparison of seroprevalence of SARS-CoV-2 infections with cumulative and imputed COVID-19 cases:

Systematic review. PLoS One, 16(4), [e0248946]. https://doi.org/10.1371/journal.pone.0248946

\section{General rights}

Copyright and moral rights for the publications made accessible in the public portal are retained by the authors and/or other copyright owners and it is a condition of accessing publications that users recognise and abide by the legal requirements associated with these rights.

For more information, or if you believe that this document breaches copyright, please contact the Bond University research repository coordinator 


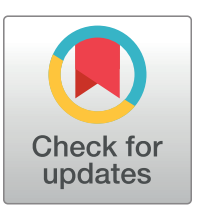

\section{openaccess}

Citation: Byambasuren 0, Dobler CC, Bell K, Rojas DP, Clark J, McLaws M-L, et al. (2021) Comparison of seroprevalence of SARS-CoV-2 infections with cumulative and imputed COVID-19 cases: Systematic review. PLOS ONE 16(4): e0248946. https://doi.org/10.1371/journal. pone. 0248946

Editor: Jean-Luc EPH Darlix, "INSERM", FRANCE

Received: November 25, 2020

Accepted: March 8, 2021

Published: April 2, 2021

Copyright: @ 2021 Byambasuren et al. This is an open access article distributed under the terms of the Creative Commons Attribution License, which permits unrestricted use, distribution, and reproduction in any medium, provided the original author and source are credited.

Data Availability Statement: All relevant data are within the manuscript and its Supporting Information files.

Funding: This study was supported by the following: National Health and Medical Research Council 1106452 Prof Paul Glasziou National Health and Medical Research Council 1080042 Prof Paul Glasziou National Health and Medical Research Council 1123733 Dr Claudia C Dobler National Health and Medical Research Council 1174523 Dr Katy Bell.
RESEARCH ARTICLE

\section{Comparison of seroprevalence of SARS-CoV-2 infections with cumulative and imputed COVID-19 cases: Systematic review}

\author{
Oyungerel Byambasuren $\oplus^{1 *}$, Claudia C. Dobler ${ }^{1}$, Katy Bell $\oplus^{2}$, Diana Patricia Rojas ${ }^{3}$, \\ Justin Clark', Mary-Louise McLaws ${ }^{4}$, Paul Glasziou ${ }^{1}$
}

1 Institute for Evidence-Based Healthcare, Bond University, Gold Coast, Australia, 2 School of Public Health, University of Sydney, Sydney, Australia, 3 College of Public Health, Medical and Veterinary Sciences, Division of Tropical Health \& Medicine, James Cook University, North Queensland, Australia, 4 School of Public Health and Community Medicine, UNSW Sydney, Kensington, Australia

* obyambas@ bond.edu.au

\section{Abstract}

\section{Background}

Accurate seroprevalence estimates of SARS-CoV-2 in different populations could clarify the extent to which current testing strategies are identifying all active infection, and hence the true magnitude and spread of the infection. Our primary objective was to identify valid seroprevalence studies of SARS-CoV-2 infection and compare their estimates with the reported, and imputed, COVID-19 case rates within the same population at the same time point.

\section{Methods}

We searched PubMed, Embase, the Cochrane COVID-19 trials, and Europe-PMC for published studies and pre-prints that reported anti-SARS-CoV-2 IgG, IgM and/or IgA antibodies for serosurveys of the general community from 1 Jan to 12 Aug 2020.

\section{Results}

Of the 2199 studies identified, 170 were assessed for full text and 17 studies representing 15 regions and 118,297 subjects were includable. The seroprevalence proportions in 8 studies ranged between $1 \%-10 \%$, with 5 studies under $1 \%$, and 4 over $10 \%$-from the notably hard-hit regions of Gangelt, Germany; Northwest Iran; Buenos Aires, Argentina; and Stockholm, Sweden. For seropositive cases who were not previously identified as COVID-19 cases, the majority had prior COVID-like symptoms. The estimated seroprevalences ranged from 0.56-717 times greater than the number of reported cumulative cases-half of the studies reported greater than 10 times more SARS-CoV-2 infections than the cumulative number of cases.

\section{Conclusions}

The findings show SARS-CoV-2 seroprevalence is well below "herd immunity" in all countries studied. The estimated number of infections, however, were much greater than the 
Competing interests: All authors have completed the ICMJE disclosure form. Prof Mary-Louise McLaws is a member of World Health Organization (WHO) Health Emergencies Program Experts Advisory Panel for Infection Prevention and Control (IPC) Preparedness, Readiness and Response to COVID-19 and WHO IPC Guidance Development Group for COVID-19. This does not alter our adherence to PLOS ONE policies on sharing data and materials. number of reported cases and deaths in almost all locations. The majority of seropositive people reported prior COVID-like symptoms, suggesting that undertesting of symptomatic people may be causing a substantial under-ascertainment of SARS-CoV-2 infections.

\section{Introduction}

Globally, over one hundred and twenty million coronavirus disease (COVID-19) cases have been reported to World Health Organization as of 15 March 2021 [1]. However, seroprevalence estimates based on immune response (serum antibodies) to SARS-CoV-2 rather than reverse transcriptase polymerase chain reaction (RT-PCR) testing [2], may provide a more accurate reflection of the true extent of SARS-CoV-2 infection among a population as many people may have not been tested when they had active infection.

Valid seroprevalence estimates for a population rely on two major factors: (i) a representative population sample and (ii) accurate antibody testing. For example, testing should not be biased by including predominantly symptomatic people or those exposed to a person with COVID-19 [3]. Inappropriate sampling will bias the estimated seroprevalence, the infection fatality rate, and the effective reproductive number (Rt) [4].

Systematic Reviews of the diagnostic accuracy SARS-CoV-2 antibodies have found concerns about bias and applicability in the available studies. The sensitivity of most antibodytests, which measure immunoglobulin ( Ig) M, IgG, and occasionally IgA antibodies against SARS-CoV-2, appears to be low in the first week after onset of symptoms and increases up to maximum value in the third week; data beyond three weeks are scarce [5-7]. Specificity of the antibody tests has been estimated to exceed $98 \%$ for most tests; however, this may still result in poor positive predictive values and high false positive rates in low prevalence settings [6]. Some evidence suggests that in infected asymptomatic people, a reduction of serum antibodies is already observed during the early convalescent phase [8].

We aimed to identify all studies that reported seroprevalence estimates for SARS-CoV-2 infection using a representative sample of the target population, and to compare to these seroprevalence estimate with the cumulative incidence of confirmed COVID-19 cases, and imputed case rates from the death rates, to establish the likely true extent of the infection among a population.

\section{Methods}

We conducted a systematic review using enhanced processes with initial report completed within two weeks, using daily short team meetings to review the progress, plan next actions, and solve discrepancies and other obstacles [9]. We also used locally developed open access automation tools and programs such as the Polyglot Search Translator, SearchRefiner, and the SRA Helper to design, refine and convert our search strategy for all the databases we searched and to speed up the screening process. We searched PubMed, Embase, Cochrane COVID-19 trials for published studies, and Europe PMC for pre-prints from 1 January to 12 August 2020. A search string composed of Medical Subject Headings (MeSH) terms and words was developed in PubMed and was translated to be run in other databases [10] (see S1 File). We also conducted forward and backward citation searches of the included studies in the Scopus citation database. No restrictions on language were imposed. Review protocol was not registered. 


\section{Inclusion criteria}

We included seroprevalence studies which attempted complete or random sample of the population with more than $25 \%$ response rate to assess overall seroprevalence in general community. We included seroprevalence testing that tested for anti-SARS-CoV-2 IgG, IgM, and IgA antibodies in combination or separately.

We excluded studies with high risk of bias in sampling, i.e. the study sample was likely not representative of the target population such as health care workers, blood donors, or dialysis patients; government reports without sufficient details to evaluate risk of bias; modelling or simulation studies even if they used real data (but sources of real data were checked for possible inclusion); lack of information about the antibody test(s) used to determine seroprevalence; and editorial or historical accounts without sufficient data to calculate the primary outcome (e.g. insufficient details to allow identification of cumulative reported cases in the population detected using RT-PCR). A list of excluded studies can be found in S1 Table with reasons for exclusion.

\section{Outcomes}

Our primary outcomes were (1) the comparison of the seroprevalence based on antibody testing in the study sample with the cumulative reported case incidence of people tested positive for SARS-CoV-2 by RT-PCR in the same sample or in the target population cross-checked by a cumulative incidence estimated from the cumulative COVID-19-specific mortality two weeks after the seroprevalence and assuming a case-fatality rate of 1\% [11]; and (2) frequency of COVID-like symptoms among the study population prior to serological testing and odds of testing positive with prominent COVID-related symptoms where data available.

\section{Study selection and screening}

Two authors (OB and $\mathrm{CCD}$ ) independently screened titles, abstracts, and full texts according to inclusion criteria. All discrepancies were resolved via group discussion with the other authors. Reasons for exclusion were documented for all full text articles deemed ineligible (S1 Table)—see PRISMA diagram (Fig 1).

\section{Data extraction}

Five authors (OB, $\mathrm{CCD}, \mathrm{KB}, \mathrm{PG}$, DPR) extracted the following information from each study and from related external sources:

- Participants: sampling frame, sample size, age, sex, setting, previous exposure or testing for COVID-19

- Methods: study authors, country or region of the study, publication type, types of tests used, date of seroprevalence sampling (to enable identification of separately reported cumulative incidence rate in the sampling frame at around the same time as seroprevalence study).

- Outcomes: study seroprevalence (point estimate and confidence interval), adjusted seroprevalence (point estimate for the population adjusted for study design and test accuracy), and cumulative COVID-19 cases in the study sample.

- Other information: when not provided in the study, we looked for publicly available data on the cumulative incidence of COVID-19 and COVID-19 specific mortality in the study population as close to the time of the study as possible. 


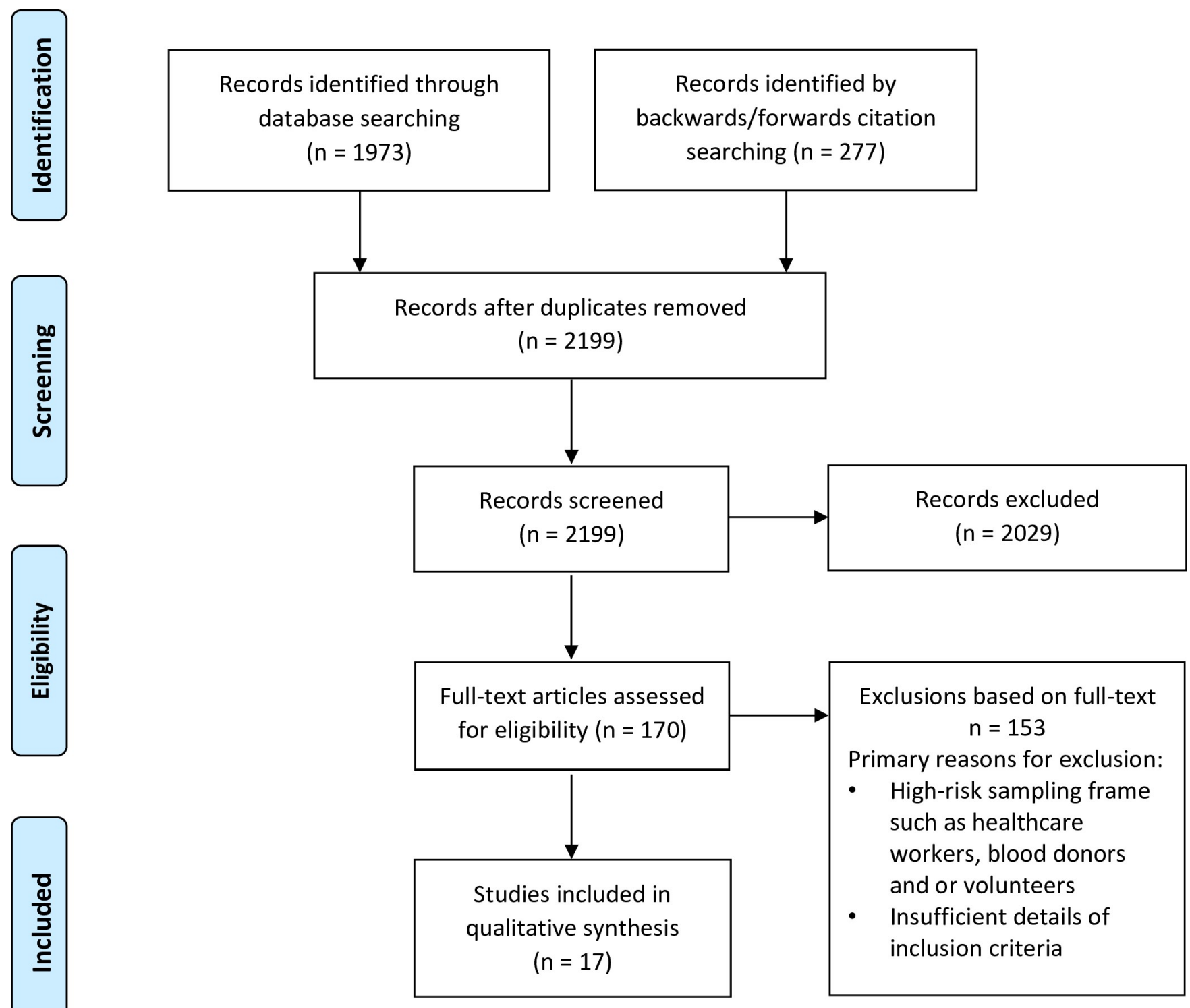

Fig 1. Screening and selection of articles for the review.

https://doi.org/10.1371/journal.pone.0248946.g001

Risk of bias assessment

We used a combination of risk of bias tools for prevalence studies [12] and diagnostic accuracy [13] and adapted the key signaling questions on sampling frame, ascertainment of immune status, acceptability of methods and tests, and appropriateness of testing and sample collection timeframe, as shown in S2 File in full.

\section{Data synthesis}

We used absolute numbers and proportions for the primary outcome. As only studies deemed to be of sufficient quality after critical appraisal were included in the analysis, no sensitivity analysis of high versus low quality studies was undertaken. We did not pool the estimates due to heterogeneity of populations and study methods. 


\section{Results}

We screened titles and abstracts of 2,199 articles and the full text of 170 articles for potential inclusion (Fig 1). The major reason for exclusion was high risk of bias in the selection of participants (Full list of excluded studies in S1 Table). Seventeen articles- 4 preprints, 11 published studies, and 2 government reports-from 15 countries (Argentina, Brazil, Spain, Hungary, Germany, Luxembourg, Switzerland, Denmark, Sweden, Finland, Iceland, the United States of America (USA), the Channel Islands, Iran, and Japan) that tested a combined total of 118,297 participants met eligibility criteria [14-30]. (Table 1.)

Four studies provide national level data [16, 17, 20, 24], five studies report a province, county or self-governing area level data $[19,22,23,26,29]$, and the rest provide a city, town, village or district level data. Seven studies tested participants over the age of 14 years [14, 17, $21,24,25,28,29]$ and ten tested population of all ages-the proportion of children and young people ( $0-19$ years) ranged from $7 \%$ to $26 \%$ and the proportion of participants aged over 60 years ranged from $7 \%$ to $37 \%$. Eight studies tested for anti-SARS-CoV-2 IgG only or IgG and IgA, the rest tested for IgG and IgM. (Table 1) Only five of the studies also collected nasopharyngeal swabs for RT-PCR testing at the same time as serologic testing [15, 17, 22-24]. Information on the serological test sensitivity and specificity is provided in S2 Table.

\section{Seroprevalence}

The seroprevalences ranged considerably (Table 2 and Fig 2): eight studies reported seroprevalence between 1\%-10\%; five studies had estimates under $1 \%[15,17-19,23]$ and four studies had estimates over $10 \%[14,21,22,26]$. The unadjusted and adjusted seroprevalence estimates in the included studies ranged from $0.22 \%$ in Rio Grande do Sul state in Brazil [23] to $53 \%$ in the Barrio Mugica slum of Buenos Aires, Argentina [14].

The cumulative case incidence in the study population (based on RT-PCR testing) was reported in five studies $[15,17,22-24]$. For the other studies we identified cumulative case incidence data from publicly available online reports. For some studies the two types of estimate were similar (e.g. Faroe island, Denmark), but for others the seroprevalence estimate was substantially higher than the cumulative case estimate (e.g. in Guilan, Iran). Further details on the study adjustment details and sources for cumulative incidence data are provided in S2 Table.

The cumulative incidence rates at the regional levels (red squares and diamonds) ranged from $0.006 \%$ in Utsunomiya, Tokyo [18] to $9.22 \%$ in Barrio Mugica slum of Buenos Aires, Argentina [14]. The calculated cumulative case incidence for regions imputed from reported COVID-19 deaths (assuming true CFR of $1 \%$, brown crosses) ranged from $0.09 \%$ in Rio Grande do Sul, Brazil [23] to 33.98\% in Neustadt-am-Rennsteig, Germany [30]. The data collection timeframes of the included studies are shown in S1 Fig in relation to the rolling 7-day average of confirmed cases in each country.

The relationship between all the outcome estimates for each study/region on the log scale are shown in Fig 2. The upper diagonal (identity) line indicates estimates that are equal to the study seroprevalence estimate, and the lower diagonal line indicates estimates that are 1/10 or $1 / 100$ that of the study seroprevalence estimate. In general, cases imputed from reported deaths are next closest to the seroprevalence estimates, although there is considerable variation in how close: imputed cases for Spain [20] matched the seroprevalence almost exactly, while those for Guilan, Iran [22] were around 1/10 of the seroprevalence. Next closest were the study cumulative case estimates, where differences in test accuracy of antibody vs RT-PCT tests may explain most of the within study differences. The estimates that differed the most from those of the study seroprevalence (furthest away from the identity line) were the reported regional 
Table 1. Characteristics of included studies $(n=17)$.

\begin{tabular}{|c|c|c|c|}
\hline $\begin{array}{l}\text { Study region, country, } \\
\text { author, publication status }\end{array}$ & Study population (sampling frame) & $\begin{array}{c}\text { Sample size, mean } \\
\text { age, sex, study dates }\end{array}$ & Type of serologic test and their Sensitivity and Specificity \\
\hline $\begin{array}{l}\text { Spanish national sero- } \\
\text { epidemiological survey } \\
\text { Pollán et al [20] } \\
\text { Published }\end{array}$ & $\begin{array}{l}\text { Randomly selected population of Spain } \\
\text { from census data }\end{array}$ & $\begin{array}{l}\mathrm{n}=61,075 \\
\text { mean age } 44 \text { years } \\
52 \% \text { female } \\
27 \text { April-11 May }\end{array}$ & IgG and IgM: Orient Gene IgM/IgG, Zhejiang Orient Gene Biotech \\
\hline $\begin{array}{l}\text { Brazilian nationwide } \\
\text { survey } \\
\text { Hallal et al [16] } \\
\text { Preprint }\end{array}$ & $\begin{array}{l}\text { Random samples of } 133 \text { large sentinel cities } \\
\text { from all } 26 \text { states and the Federal District in } \\
\text { Brazil }\end{array}$ & $\begin{array}{l}\mathrm{n}=24,995 \\
\text { mean age } 43 \\
58 \% \text { female } \\
14-21 \text { May }\end{array}$ & $\begin{array}{l}\text { IgG and IgM: WONDFO } 459 \text { SARS-CoV-2 Antibody Test (Wondfo } \\
\text { Biotech Co., Guangzhou, China) }\end{array}$ \\
\hline $\begin{array}{l}\text { Hungary } \\
\text { Merkely et al [17] } \\
\text { Published }\end{array}$ & $\begin{array}{l}\text { Random sampling of representative } \\
\text { Hungarian population over } 14 \text { years of age. }\end{array}$ & $\begin{array}{l}\mathrm{n}=10,474 \\
\text { mean age } 49 \text { years } \\
53.6 \% \text { female } \\
1-16 \text { May }\end{array}$ & $\begin{array}{l}\text { IgG: SARS-CoV2 IgG Reagent Kit, Abbott Laboratories, Irving, TX, } \\
\text { USA }\end{array}$ \\
\hline $\begin{array}{l}\text { Luxembourg } \\
\text { Snoeck et al [24] } \\
\text { Preprint }\end{array}$ & $\begin{array}{l}\text { Random sample of Luxembourg population } \\
\text { over age of } 18(n=514,921)\end{array}$ & $\begin{array}{l}\mathrm{n}=1820 \\
\text { mean age } 47 \text { years } \\
51 \% \text { female } \\
16 \text { April-5 May }\end{array}$ & $\begin{array}{l}\text { IgG and IgA: CE-labelled ELISA kits most recent versions from } \\
\text { Euroimmun. }\end{array}$ \\
\hline $\begin{array}{l}\text { Rio Grande do Sul, Brazil } \\
\text { Silviera et al [23] } \\
\text { Published }\end{array}$ & $\begin{array}{l}\text { Random sample of population in Rio } \\
\text { Grande do Sul state (population } 11.3 \mathrm{mln} \text { ) }\end{array}$ & $\begin{array}{l}\mathrm{n}=4500 \\
\text { mean age } 48 \text { years } \\
59 \% \text { female } \\
\text { 9-11 May }\end{array}$ & $\begin{array}{l}\text { IgG and IgM: WONDFO SARS-CoV-2 Antibody Test (Wondfo } \\
\text { Biotech Co., Guangzhou, China) }\end{array}$ \\
\hline $\begin{array}{l}\text { Faroe Island, Denmark } \\
\text { Petersen et al [19] } \\
\text { Published }\end{array}$ & $\begin{array}{l}\text { Randomly selected population of the island } \\
\text { (population } 52,154 \text { ), }\end{array}$ & $\begin{array}{l}\mathrm{n}=1075 \\
\text { Mean age } 42 \text { years } \\
50 \% \text { female } \\
27 \text { April-1 May }\end{array}$ & $\begin{array}{l}\text { IgG and IgM: SARS-CoV-2 Ab ELISA kit (Beijing Wantai Biologic } \\
\text { Pharmacy Enterprise) }\end{array}$ \\
\hline $\begin{array}{l}\text { LA county, USA } \\
\text { Sood et al [25] } \\
\text { Published }\end{array}$ & Random sample of LA county population & $\begin{array}{l}\mathrm{n}=863 \\
\text { mean age } 44 \text { years } \\
60 \% \text { female } \\
10-14 \text { April }\end{array}$ & IgG and IgM: Lateral Flow Immunoassay test (Premier Biotech) \\
\hline $\begin{array}{l}\text { Jersey Island } \\
\text { The Channel Islands [29] } \\
\text { Report }\end{array}$ & $\begin{array}{l}\text { Random sample of adult resident } \\
\text { population of Island of Jersey living in } \\
\text { private households }\end{array}$ & $\begin{array}{l}\mathrm{n}=855 \\
\text { mean age } 48 \text { years } \\
53 \% \text { female } \\
29 \text { April-5 May }\end{array}$ & $\begin{array}{l}\text { IgG and IgM: Lateral Flow Immunoassay (Healgen COVID-19 IgG/ } \\
\text { IgM) }\end{array}$ \\
\hline $\begin{array}{l}\text { Guilan, Iran } \\
\text { Shakiba et al [22] } \\
\text { Published }\end{array}$ & $\begin{array}{l}\text { Random sample of population of Guilan } \\
\text { province, Iran (population } 2,354,848 \text { ) }\end{array}$ & $\begin{array}{l}\mathrm{n}=528 \\
\text { mean age } 35 \text { years } \\
51 \% \text { female } \\
\text { April }\end{array}$ & IgG and IgM: VivaDiag COVID-19 IgM/IgG from VivaChek \\
\hline $\begin{array}{l}\text { Reykjavik, Iceland } \\
\text { Gudbjartsson et al [15] } \\
\text { Published }\end{array}$ & $\begin{array}{l}\text { Population of greater Reykjavik area who } \\
\text { had not been tested with PCR or had been } \\
\text { tested and negative }\end{array}$ & $\begin{array}{l}\mathrm{n}=4843 \\
\text { Mean age } 48 \text { years } \\
38 \% \text { female } \\
27 \text { April- } 5 \text { June }\end{array}$ & $\begin{array}{l}\text { pan-Ig: IgM, IgG, \& IgA against nucleoprotein (N) (Roche); the } \\
\text { receptor binding domain (Wantai); IgM \& IgG against N (EDI/ } \\
\text { Eagle); and IgG \& IgA against the spike protein (Euroimmun). }\end{array}$ \\
\hline $\begin{array}{l}\text { Geneva, Switzerland } \\
\text { Stringhini et al [27] } \\
\text { Published }\end{array}$ & $\begin{array}{l}\text { Random sample of Bus Santé study } \\
\text { participants, canton of Geneva }\end{array}$ & $\begin{array}{l}\mathrm{n}=1956 \\
\text { mean age } 44 \text { years } \\
53 \% \text { female } \\
20 \text { Apr-10 May }\end{array}$ & $\begin{array}{l}\text { IgG: commercially available ELISA for IgG (Euroimmun AG, } \\
\text { Lübeck, Germany) }\end{array}$ \\
\hline $\begin{array}{l}\text { Stockholm, Sweden } \\
\text { Roxhed et al [21] } \\
\text { Preprint }\end{array}$ & $\begin{array}{l}\text { Random household sample of adults }(20- \\
74 \text { years) in Stockholm }\end{array}$ & $\begin{array}{l}\mathrm{n}=1097 \\
\text { Mean age } 47 \text { years } \\
55 \% \text { female } \\
\text { April-May }\end{array}$ & $\begin{array}{l}\text { IgG: commercially available ELISA for IgG against } \mathrm{S} 1 \text { and } \mathrm{N} \\
\text { proteins }\end{array}$ \\
\hline $\begin{array}{l}\text { Five university hospital } \\
\text { districts, Finland } \\
\text { Finnish Institute for Health } \\
\text { and Welfare Report [28] }\end{array}$ & $\begin{array}{l}\text { Random sampling of adult population from } \\
5 \text { hospital districts in southern Finland } \\
\text { since } 1 \text { June }\end{array}$ & $\begin{array}{l}\mathrm{n}=1056 \\
\text { Age range } 18-69 \\
\text { years } \\
1 \text { June- } 6 \text { Sep }\end{array}$ & $\begin{array}{l}\text { IgG: against nucleoprotein and spike glycoprotein } \mathrm{S} 1 \text { and } \mathrm{S} 2 \text {, the } \\
\text { antigens manufactured by The Native Antigen Company }\end{array}$ \\
\hline $\begin{array}{l}\text { Gangelt, Germany } \\
\text { Streeck et al [26] } \\
\text { Published }\end{array}$ & $\begin{array}{l}\text { Random sample of population of Gangelt, } \\
\text { Germany }(\mathrm{n}=12,597) \text { from civil register }\end{array}$ & $\begin{array}{l}\mathrm{n}=919 \\
\text { mean age } 53 \text { years } \\
51 \% \text { female } \\
31 \mathrm{Mar}-6 \mathrm{Apr}\end{array}$ & $\begin{array}{l}\text { IgG and IgA: ELISA on the EUROIMMUN Analyzer I platform } \\
\text { (most recent CE version for IgG ELISA as of April 2020) }\end{array}$ \\
\hline
\end{tabular}


Table 1. (Continued)

\begin{tabular}{|c|c|c|c|}
\hline $\begin{array}{l}\text { Study region, country, } \\
\text { author, publication status }\end{array}$ & Study population (sampling frame) & $\begin{array}{l}\text { Sample size, mean } \\
\text { age, sex, study dates }\end{array}$ & Type of serologic test and their Sensitivity and Specificity \\
\hline $\begin{array}{l}\text { Barrio Mugica, Buenos } \\
\text { Aires, Argentina } \\
\text { Figar et al [14] } \\
\text { Preprint }\end{array}$ & $\begin{array}{l}\text { Random sample of residents over } 14 \text { years } \\
\text { of age, Barrio Mugica slum }(\mathrm{n}=40,000) \\
\text { Buenos Aires city }\end{array}$ & $\begin{array}{l}\mathrm{n}=873 \\
\text { median age } 38 \text { years } \\
57 \% \text { female } \\
10-26 \text { June }\end{array}$ & $\begin{array}{l}\text { IgG: COVIDAR IgG ELISA (Laboratorio Lemos SRL, Buenos Aires, } \\
\text { Argentina) }\end{array}$ \\
\hline $\begin{array}{l}\text { Utsunomiya, Japan } \\
\text { Nawa et al [18] } \\
\text { Published }\end{array}$ & $\begin{array}{l}\text { Random selection of residents in } \\
\text { Utsunomiya City in Tochigi Prefecture, } \\
\text { Greater Tokyo, Japan }\end{array}$ & $\begin{array}{l}\mathrm{n}=742 \\
\text { Mean age } 44 \text { years } \\
52.6 \% \text { female } \\
14 \text { June-5 July }\end{array}$ & $\begin{array}{l}\text { IgG: SARS-CoV2 IgG chemiluminescence assay from Shenzhen } \\
\text { YHLO Biotech Co., Ltd., Shenzhen, China }\end{array}$ \\
\hline $\begin{array}{l}\text { Neustadt-am-Rennsteig, } \\
\text { Germany } \\
\text { Weis et al [30] } \\
\text { Published }\end{array}$ & $\begin{array}{l}\text { Whole population of Neustadt-am- } \\
\text { Rennsteig village, Germany (population } \\
883 \text { ) }\end{array}$ & $\begin{array}{l}\mathrm{N}=626 \\
\text { Mean age } 60 \text { years } \\
53 \% \text { female } \\
12-22 \text { May }\end{array}$ & $\begin{array}{l}\text { IgG: two ELISA (Epitope Diagnostics Inc., San Diego, USA, } \\
\text { Euroimmun, Lübeck, Germany) and four chemiluminescence } \\
\text { assays (DiaSorin, Saluggia, Italy, Snibe Co., Ltd., Shenzhen, China, } \\
\text { Abbott, Chicago, USA, and Roche, Basel Switzerland) }\end{array}$ \\
\hline
\end{tabular}

https://doi.org/10.1371/journal.pone.0248946.t001

case estimates, with several falling below the $1 / 100$ seroprevalence line, some notably so (Guilan, Iran) [22].

\section{Ratio of seroprevalence to cumulative cases}

Table 2 compares estimates of seroprevalence estimates to the cumulative reported cases. For two studies-Rio Grande do Sul, Brazil, and the Faroe Islands, the seroprevalence was less than cumulative cases, but numbers were small. For seven other studies the ratio was less than

Table 2. Estimated cumulative incidence of infections based on seroprevalence estimates and comparison with the number of reported cases and imputed cases from death rate.

\begin{tabular}{|c|c|c|c|c|c|}
\hline Study location & $\begin{array}{l}\text { Seroprevalence from study / } \\
\text { adjusted seroprevalence }\end{array}$ & $\begin{array}{l}\text { Cumulative } \\
\text { cases }\end{array}$ & $\begin{array}{l}\text { Cases imputed } \\
\text { from deaths }\end{array}$ & $\begin{array}{l}\text { Ratio of adjusted } \\
\text { seroprevalence to cumulative } \\
\text { cases }\end{array}$ & $\begin{array}{l}\text { Ratio of adjusted seroprevalence to } \\
\text { cases imputed from deaths }\end{array}$ \\
\hline $\begin{array}{l}\text { Rio Grande do Sul, } \\
\text { Brazil }\end{array}$ & $0.22 \% / 0.22 \%$ & $0.396 \%$ & $0.09 \%$ & 0.56 & 2.53 \\
\hline $\begin{array}{l}\text { Faroe island, } \\
\text { Denmark }\end{array}$ & $0.56 \% / 0.70 \%$ & $0.79 \%$ & NA & 0.88 & NA \\
\hline $\begin{array}{l}\text { Neustadt-am- } \\
\text { Rennsteig, Germany }\end{array}$ & $8.39 \% / 8.39 \%$ & $5.55 \%$ & $33.98 \%$ & 1.51 & 0.25 \\
\hline Reykjavik, Iceland & $0.90 \% / 0.90 \%$ & $0.50 \%$ & $0.30 \%$ & 1.80 & 3.00 \\
\hline Brazil & $1.40 \% / 1.00 \%$ & $0.49 \%$ & $1.90 \%$ & 2.04 & 0.53 \\
\hline Luxembourg & $1.92 \% / 2.09 \%$ & $0.62 \%$ & $1.47 \%$ & 3.37 & 1.42 \\
\hline Gangelt, Germany & $13.60 \% / 15.50 \%$ & $3.10 \%$ & $8.42 \%$ & 5.00 & 1.84 \\
\hline $\begin{array}{l}\text { Barrio Mugica, } \\
\text { Argentina }\end{array}$ & $53.40 \% / 53.40 \%$ & $9.22 \%$ & $13.75 \%$ & 5.79 & 3.88 \\
\hline Geneva, Switzerland & $8.28 \% / 8.28 \%$ & $1.01 \%$ & $4.85 \%$ & 8.23 & 1.71 \\
\hline Jersey Island & $3.10 \% / 3.10 \%$ & $0.30 \%$ & $1.53 \%$ & 10.33 & 2.03 \\
\hline Stockholm, Sweden & $10.48 \% / 10.48 \%$ & $0.85 \%$ & $7.00 \%$ & 12.33 & 1.50 \\
\hline Hungary & $0.66 \% / 0.68 \%$ & $0.04 \%$ & $0.45 \%$ & 18.89 & 1.50 \\
\hline Southern Finland & $3.03 \% / 3.0 \%$ & $0.14 \%$ & $0.6 \%$ & 20.78 & 4.96 \\
\hline LA county, USA & $4.05 \% / 4.65 \%$ & $0.10 \%$ & $0.36 \%$ & 46.34 & 12.76 \\
\hline Spain & $5.00 \% / 5.00 \%$ & $0.08 \%$ & $5.00 \%$ & 62.50 & 1.00 \\
\hline $\begin{array}{l}\text { Utsunomiya City, } \\
\text { Japan }\end{array}$ & $0.40 \% / 1.23 \%$ & $0.006 \%$ & NA & 193.30 & NA \\
\hline Guilan, Iran & $22.16 \% / 33.00 \%$ & $0.05 \%$ & $2.62 \%$ & 717.39 & 12.60 \\
\hline
\end{tabular}

https://doi.org/10.1371/journal.pone.0248946.t002 


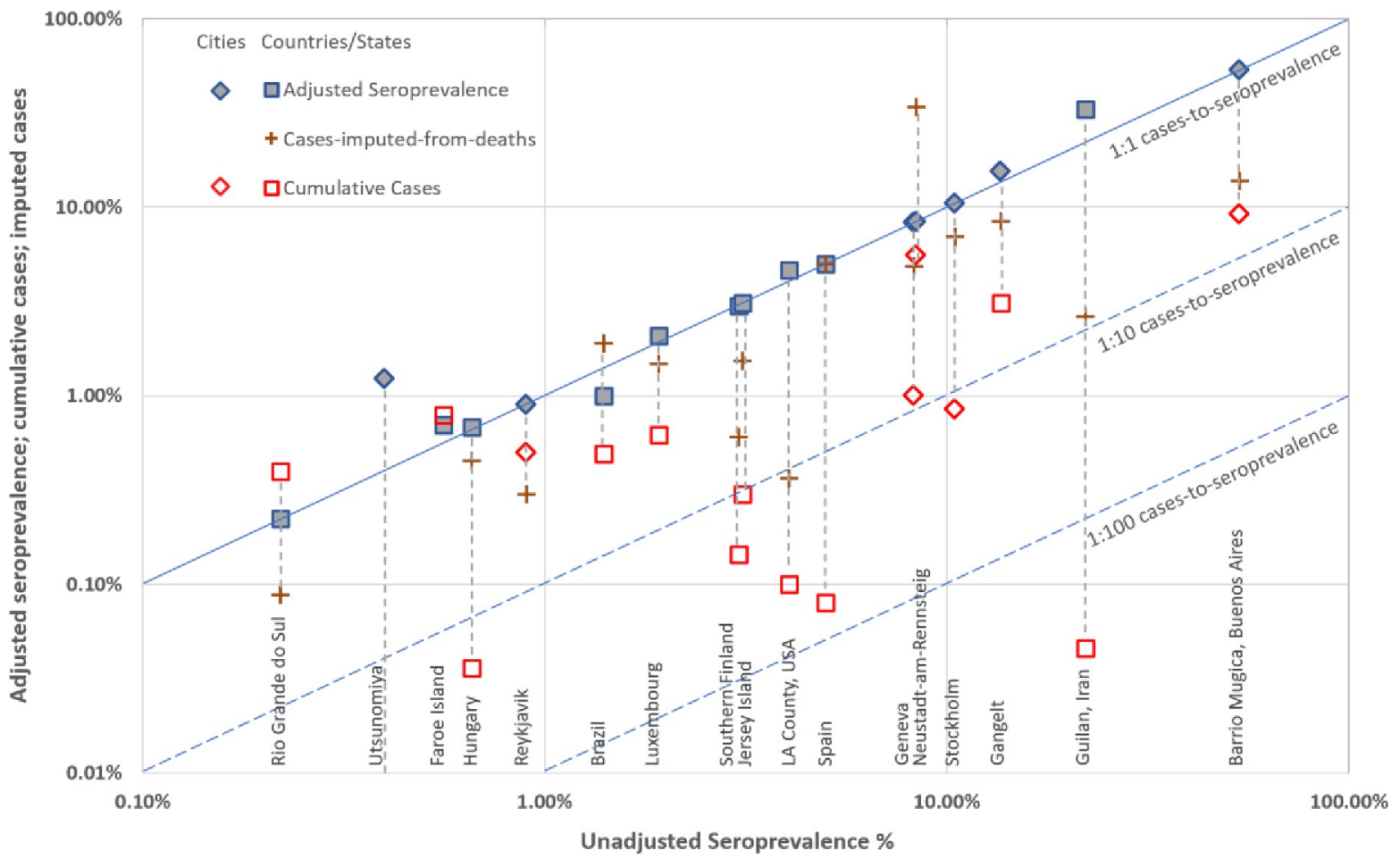

Fig 2. Log-log plot of study seroprevalence ( $\mathrm{x}$-axis) vs two cumulative case estimators for each study. Diagonal lines indicate rates equal to seroprevalence (solid) or 1/10 seroprevalence (dashed).

https://doi.org/10.1371/journal.pone.0248946.g002

10. The highest ratio was in Guilan, Iran, where the estimation of infections was 717 times greater than the reported cases as of April 2020. Two studies did not report any COVID-19 related deaths among the participants so we could not impute case estimates for these studies $[17,18]$. For those studies we could impute the cumulative cases from deaths, the ratios were generally much closer to 1 , three being less than 1, and only two over 10 .

\section{Symptoms}

Typical COVID-like symptoms prior to serologic testing [31] could help assess possible untested or undetected cases. Nine of the 17 studies provided data on prior symptoms and measures varied (Table 3). Between $17 \%$ and $83 \%$ of the sero-positive participants in six studies reported having typical COVID-like symptoms in the 2 weeks to 3 months prior to the serologic testing. Prevalence of COVID-like symptoms were significantly more common among seropositive participants compared to the sero-negative participants. Positive serologic testing was 1.5 to 8.1 times more likely in people who had had any acute respiratory infection (ARI) symptoms; for the individual symptoms this ranged from 2-fold (fever) to 46-fold (loss of smell and taste). Three studies also reported prevalence of other non-specific symptoms such as headache, chest pain, skin rash, nausea, and fatigue among the participants $[17,24,30]$.

\section{Risk of bias of included studies}

Table 4 summarizes the overall risk of bias assessment of the 17 included studies (see S2 File). Most studies had low risk of bias for the sampling frame as they recruited participants randomly from the general population (Domain 1). Majority of the studies reported response rate over $50 \%$. Five studies reported response rate in lower 30\% or unclear (Domain 2). Domain 3 
Table 3. Frequency of COVID-like or respiratory symptoms.

\begin{tabular}{|c|c|c|c|c|c|c|}
\hline \multirow[t]{2}{*}{ Study ID } & \multirow[t]{2}{*}{$\begin{array}{l}\text { COVID-like symptoms among sero- } \\
\text { positives (\%) (time period) }\end{array}$} & \multirow[t]{2}{*}{$\begin{array}{c}\text { COVID-like symptoms among } \\
\text { sero-negatives }(\%)\end{array}$} & \multicolumn{4}{|c|}{$\begin{array}{c}\text { Odds ratio for symptoms in sero-positives versus } \\
\text { sero-negatives }\end{array}$} \\
\hline & & & $\begin{array}{l}\text { Any ARI } \\
\text { symptoms }\end{array}$ & Fever & Cough & $\begin{array}{l}\text { Loss of smell } \\
\text { and taste }\end{array}$ \\
\hline $\begin{array}{l}\text { Spanish national survey (Pollán } \\
\text { et al [20]) }\end{array}$ & $\mathbf{5 2 \%}($ since $1 \mathrm{Feb})$ & NA & 8.1 & NA & NA & NA \\
\hline Hungary (Merkely et al [17]) & $\mathbf{5 5 \%}$ (previous 2 months) & $42 \%$ & 1.5 & 1.9 & 1.2 & 8 \\
\hline Luxembourg (Snoeck et al [24]) & $\mathbf{5 4 \%}$ (last 14 days) & NA & NA & NA & NA & NA \\
\hline LA county, USA (Sood et al [25]) & $77 \%$ (previous 2 months) & $25 \%$ & NA & 2.8 & NA & 4.1 \\
\hline Guilan, Iran (Shakiba et al [22]) & $\mathbf{3 1 \%}$ (previous 3 months) & $22 \%$ & 2.2 & NA & NA & NA \\
\hline $\begin{array}{l}\text { Stockholm, Sweden (Roxhed et al } \\
\text { [21]) }\end{array}$ & 63\%-83\% (previous 2 months) & $39 \%$ & NA & NA & NA & NA \\
\hline $\begin{array}{l}\text { Gangelt, Germany (Streeck et al } \\
[26])\end{array}$ & $\begin{array}{l}\mathbf{7 8 \%} \text { (since beginning of the pandemic on } \\
15 \mathrm{Feb} \text { ) }\end{array}$ & NA & NA & 4.9 & 2.8 & 18.5 \\
\hline $\begin{array}{l}\text { Barrio Mugica, Argentina (Figar } \\
\text { et al [14]) }\end{array}$ & $\mathbf{1 7 \%}$ (fever in the last 2 months) & NA & NA & NA & NA & NA \\
\hline $\begin{array}{l}\text { Neustadt-am-Rennsteig, Germany } \\
\text { (Weis et al [30]) }\end{array}$ & 63\% (last 2 months) & $21 \%$ & NA & 5.8 & 4.8 & 46.5 \\
\hline
\end{tabular}

assessed the potential to over- or underestimate the seroprevalence based on the diagnostic accuracy of the individual antibody tests used in each study. Although each study provided specificity and sensitivity for the tests based on internal or external (manufacturer) validation, it was difficult to confidently evaluate the impact on the study results without a single-source validation that would enable unbiased comparison. All studies but one used the same test and type of test specimen in all study participants (Domain 4). The Spanish national serosurvey did not venipuncture children and used only the rapid test (finger prick blood sample) and lab test in adults. We evaluated the appropriateness of the timing of testing as low risk of bias as all studies reported the dates of sample collection and testing as occurring after their local "pandemic wave" had passed. (Domain 5)

\section{Discussion}

The seroprevalence rates in eight studies ranged between 1\%-10\%, with 5 studies under 1\%, and 4 studies over 10\%-notably hard-hit regions of Gangelt, Germany, Northwest Iran, the Barrio Mugica slum of Buenos Aires, Argentina, and Stockholm, Sweden. For all but two studies, the seroprevalence estimate was higher than the cumulative reported case incidence, by a factor between 1.5 to 717 times higher. However, the seroprevalence estimates were generally much closer to the cumulative incidence imputed from deaths. Finally, we noted that many of the seropositive cases had either typical or atypical symptoms.

The difference between seroprevalence and cumulative reported incidence might be explained by three components: (i) asymptomatic cases (ii) atypical or pauci-symptomatic cases, or (iii) the lack of access to, and uptake, of testing in different regions and countries. The asymptomatic proportion found in studies of quarantine is around 17\% [32], and so would only explain a small proportion of the difference. The reports of symptoms suggest that atypical symptoms, such as anosmia, and as well as fever and cough were common in the seropositive but undetected cases. We further examined the difference between seroprevalence and cumulative incidence by using a cumulative incidence imputed from the COVID-19 death rates. A notable example is the study in North-West Iran where the apparent case fatality rate is amongst the highest in the world, and there is also some evidence of under reporting of COVID-19 deaths based on the comparison of excess deaths. 
Table 4. Risk of bias in 14 included studies.

\begin{tabular}{|c|c|c|c|c|c|}
\hline $\begin{array}{l}\text { Risk of bias assessment questions } \\
\text { Included studies }\end{array}$ & $\begin{array}{l}\text { 1. Was the sampling } \\
\text { frame a true or close } \\
\text { representation of the } \\
\text { target population? }\end{array}$ & $\begin{array}{l}\text { 3. Is the diagnostic test } \\
\text { used likely to correctly } \\
\text { classify all past infections } \\
\text { in the target (at risk) } \\
\text { population? }\end{array}$ & $\begin{array}{l}\text { 3. Is the diagnostic test } \\
\text { used likely to correctly } \\
\text { classify all past infections } \\
\text { in the target (at risk) } \\
\text { population? }\end{array}$ & $\begin{array}{l}\text { 4. Was the same } \\
\text { diagnostic test } \\
\text { used for all } \\
\text { subjects? }\end{array}$ & $\begin{array}{l}\text { 5. Was the } \\
\text { period of testing } \\
\text { appropriate? }\end{array}$ \\
\hline Spanish national sero-survey & $\odot$ & 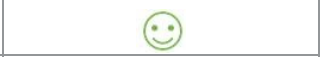 & $\approx$ & $\approx$ & $\odot$ \\
\hline Brazilian nationwide survey & (2) & 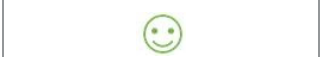 & 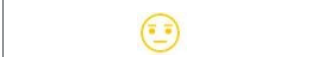 & 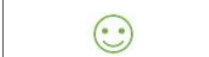 & (2) \\
\hline Hungary & ( & $(-)$ & $\approx$ & $(-)$ & $\odot$ \\
\hline Luxembourg & (2) & 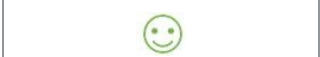 & 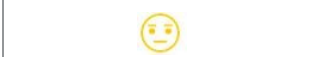 & 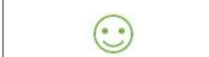 & (-) \\
\hline Rio Grande do Sul, Brazil & (2) & 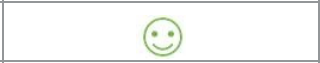 & $\approx$ & 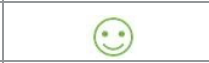 & (2) \\
\hline Faroe island, Denmark & (2) & 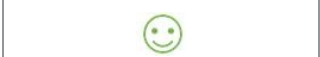 & 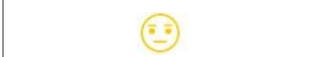 & 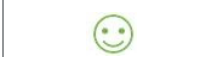 & (-) \\
\hline LA county, USA & ( & 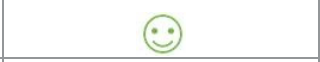 & $\approx$ & 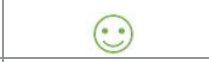 & 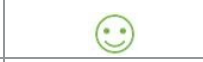 \\
\hline Jersey Island, Channel Islands & 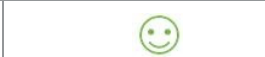 & $\odot$ & 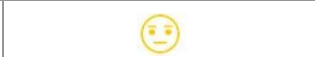 & $\odot$ & 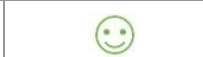 \\
\hline Guilan, Iran & (;) & $\approx$ & $\approx$ & $\odot$ & (;) \\
\hline Reykjavik, Iceland & (-) & $\approx$ & $\approx$ & $\odot$ & $\odot$ \\
\hline Geneva, Switzerland & (2) & $\approx$ & $\approx$ & (;) & (;) \\
\hline Stockholm, Sweden & (;) & $\odot$ & $\approx$ & $\odot$ & $\odot$ \\
\hline Five uni hospital districts, Finland & (2) & (-) & $\approx$ & (-) & (;) \\
\hline Gangelt, Germany & (-) & $\odot$ & $\approx$ & $\odot$ & $\odot$ \\
\hline Barrio Mugica, Argentina & 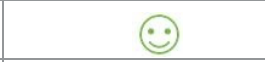 & $\approx$ & $\approx$ & (-) & (-) \\
\hline Utsunomiya, Japan & (;) & $\approx$ & $\approx$ & (-) & (;) \\
\hline Neustadt-am-Rennsteig, Germany & 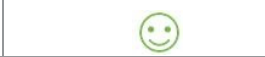 & $\odot$ & $\approx$ & 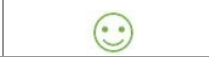 & (;) \\
\hline
\end{tabular}

Green smiley face denotes low risk of bias; yellow straight face-moderate or unclear risk; and red sad face-high risk of bias. 
because of the inclusion of studies with high risk of bias. The estimated under-ascertainment of infections based on seroprevalence was 6 to 24 times the number of cumulative reported cases in a study from the United States [35], most of the areas they investigated had an estimated infection rates at least 10 times greater than the reported cases, which was similar to our findings.

The results of this review have several implications for policy and practice. First, in all studies the estimated seroprevalences falls well short of that required for herd immunity suggesting that herd immunity is unlikely to be achieved without mass vaccinations. Herd immunity notion is often not based on robust data and policy makers need as much reliable data to make better decisions as possible. Additionally, infection fatality rates are shown to increase severalfold as the age of the people advance, further proving that herd immunity should not be pursued through the natural course of a pandemic [36]. Reaching herd immunity does not guarantee low or zero disease prevalence and susceptible individuals will still remain at risk of infection [37]. Second, studies in regions with relatively thorough symptom-based testing and detection show only a modest gap between the seroprevalence and the case cumulative incidence, suggesting that much of the gap between reported cases and seroprevalence is likely to be due to undetected symptomatic cases. Third, the short serial interval, days 3 to 5 , post-exposure enables the exposed person to become a source of transmission prior to developing symptoms [38]. Estimating cumulative cases on test-and-trace approaches that test only symptomatic contacts will underestimates of community seroprevalence. Fourth, the variation and incompleteness of methods used by the studies points to the need for better standardisation, design, and reporting of seroprevalence studies, including the need for better questioning and reporting of subjects, prior history of RT-PCR testing, and history of symptoms.

Routine testing for an immune response to COVID-19 in recovered patients allows not only evaluation of the transmissibility of infection in general and specific populations, but would provide improved estimations of attack rates and infection fatality rates, estimates of possible immunity and evidence of reinfection [39-41]. The detection of antibodies established from the studies we analysed does not infer herd immunity levels in their populations. SARS-CoV-2 shares 79.6\% sequence identity to SARS-CoV [42], and the peak level of IgG/ neutralising antibodies in recovered SARS-CoV patients occurred at 4-6 months before declining [43]. Knowing the duration of immunity could inform strategic public health approaches until a vaccine is available. Accurate estimates of immunity will not only require repeat antibody testing among the population, but also establishing the association between a positive antibody response and protective immunity against the disease. The current unknown duration of IgG response and its association with disease immunity also raises questions about the validity of an "immunity passport", especially past a probable peak at 4-6 months post infection $[43,44]$.

Findings of this review should help inform policy globally, but also trigger improved research methods and better reporting of any future studies on seroprevalence. When there is a large gap between seroprevalence estimates and incidence rates, strategies to extend case finding and testing needs to be implemented. Evidence-based and targeted public health measures informed by accurate real-world data will help us successfully navigate the uncertain dynamics of this new pandemic.

\section{Supporting information}

S1 Checklist. PRISMA 2009 checklist. (DOC) 
S1 Fig. Figure showing the data collection timeframes of included studies in relation to the rolling 7-day average of confirmed cases in each country.

(DOCX)

S1 Table. Table of excluded full text articles with reasons.

(DOCX)

S2 Table. Table with serological test sensitivity and specificity, adjustment details of studies and sources for cumulative incidence data.

(DOCX)

S1 File. Full search strategy.

(DOCX)

S2 File. Full signalling questions for risk of bias assessment.

(DOCX)

\section{Acknowledgments}

We thank the authors of eligible manuscripts for their replies to our queries.

\section{Author Contributions}

Conceptualization: Oyungerel Byambasuren, Claudia C. Dobler, Paul Glasziou.

Data curation: Oyungerel Byambasuren, Claudia C. Dobler, Katy Bell, Diana Patricia Rojas, Justin Clark, Mary-Louise McLaws, Paul Glasziou.

Formal analysis: Claudia C. Dobler, Katy Bell, Paul Glasziou.

Investigation: Katy Bell, Diana Patricia Rojas, Justin Clark.

Methodology: Oyungerel Byambasuren, Claudia C. Dobler, Katy Bell, Diana Patricia Rojas, Justin Clark, Mary-Louise McLaws, Paul Glasziou.

Project administration: Oyungerel Byambasuren.

Resources: Oyungerel Byambasuren.

Supervision: Paul Glasziou.

Visualization: Oyungerel Byambasuren.

Writing - original draft: Oyungerel Byambasuren, Paul Glasziou.

Writing - review \& editing: Oyungerel Byambasuren, Claudia C. Dobler, Katy Bell, Diana Patricia Rojas, Justin Clark, Mary-Louise McLaws, Paul Glasziou.

\section{References}

1. World Health Organization. WHO Coronavirus Disease (COVID-19) Dashboard 2020 [Available from: https://covid19.who.int/.

2. Wu J, Liu J, Li S, Peng Z, Xiao Z, Wang X, et al. Detection and analysis of nucleic acid in various biological samples of COVID-19 patients. Travel Medicine and Infectious Disease. 2020:101673. https://doi. org/10.1016/j.tmaid.2020.101673 PMID: 32311437

3. Prevention. CfDCa. Commercial Laboratory Seroprevalence Survey Data 2020 [Available from: https:// www.cdc.gov/coronavirus/2019-ncov/cases-updates/commercial-lab-surveys.html.

4. Sanche S, Lin YT, Xu C, Romero-Severson E, Hengartner N, Ke R. High Contagiousness and Rapid Spread of Severe Acute Respiratory Syndrome Coronavirus 2. Emerging Infectious Disease journal. 2020; 26(7):1470. https://doi.org/10.3201/eid2607.200282 PMID: 32255761 
5. Long QX, Liu BZ, Deng HJ, Wu GC, Deng K, Chen YK, et al. Antibody responses to SARS-CoV-2 in patients with COVID-19. Nat Med. 2020; 26(6):845-8. https://doi.org/10.1038/s41591-020-0897-1 PMID: 32350462

6. Deeks JJ, Dinnes J, Takwoingi Y, Davenport C, Spijker R, Taylor-Phillips S, et al. Antibody tests for identification of current and past infection with SARS-CoV-2. Cochrane Database of Systematic Reviews. 2020(6). https://doi.org/10.1002/14651858.CD013652 PMID: 32584464

7. Lisboa Bastos M, Tavaziva G, Abidi SK, Campbell JR, Haraoui L-P, Johnston JC, et al. Diagnostic accuracy of serological tests for covid-19: systematic review and meta-analysis. BMJ. 2020; 370:m2516. https://doi.org/10.1136/bmj.m2516 PMID: 32611558

8. Long Q-X, Tang X-J, Shi Q-L, Li Q, Deng H-J, Yuan J, et al. Clinical and immunological assessment of asymptomatic SARS-CoV-2 infections. Nature Medicine. 2020. https://doi.org/10.1038/s41591-0200965-6 PMID: 32555424

9. Clark J, Glasziou P, Del Mar C, Bannach-Brown A, Stehlik P, Scott AM. A full systematic review was completed in 2 weeks using automation tools: a case study. J Clin Epidemiol. 2020; 121:81-90. https:// doi.org/10.1016/j.jclinepi.2020.01.008 PMID: 32004673

10. Clark JM, Sanders S, Carter M, Honeyman D, Cleo G, Auld Y, et al. Improving the translation of search strategies using the Polyglot Search Translator: a randomized controlled trial. J Med Libr Assoc. 2020; 108(2):195-207. https://doi.org/10.5195/jmla.2020.834 PMID: 32256231

11. Khan S. The true case fatality of COVID-19: An analytical solution. medRxiv. 2020:2020.05.17.20104554.

12. Hoy $D$, Brooks $P$, Woolf $A$, Blyth $F$, March $L$, Bain $C$, et al. Assessing risk of bias in prevalence studies: modification of an existing tool and evidence of interrater agreement. J Clin Epidemiol. 2012; 65 (9):934-9. https://doi.org/10.1016/j.jclinepi.2011.11.014 PMID: 22742910

13. Whiting PF, Rutjes AW, Westwood ME, Mallett S, Deeks JJ, Reitsma JB, et al. QUADAS-2: a revised tool for the quality assessment of diagnostic accuracy studies. Ann Intern Med. 2011; 155(8):529-36. https://doi.org/10.7326/0003-4819-155-8-201110180-00009 PMID: 22007046

14. Figar S, Pagotto V, Luna L, Salto J, Wagner Manslau M, Mistchenko A, et al. Community-level SARSCoV-2 Seroprevalence Survey in urban slum dwellers of Buenos Aires City, Argentina: a participatory research. medRxiv; 2020.

15. Gudbjartsson DF, Norddahl GL, Melsted P, Gunnarsdottir K, Holm H, Eythorsson E, et al. Humoral Immune Response to SARS-CoV-2 in Iceland. New England Journal of Medicine. 2020. https://doi.org/ 10.1056/NEJMoa2026116 PMID: 32871063

16. Hallal P, Hartwig F, Horta B, Victora GD, Silveira M, Struchiner C, et al. Remarkable variability in SARSCoV-2 antibodies across Brazilian regions: nationwide serological household survey in 27 states. medRxiv. 2020:2020.05.30.20117531.

17. Merkely B, Szabó AJ, Kosztin A, Berényi E, Sebestyén A, Lengyel C, et al. Novel coronavirus epidemic in the Hungarian population, a cross-sectional nationwide survey to support the exit policy in Hungary. Geroscience. 2020; 42(4):1063-74. https://doi.org/10.1007/s11357-020-00226-9 PMID: 32677025

18. Nawa N, Kuramochi J, Sonoda S, Yamaoka Y, Nukui Y, Miyazaki Y, et al. Seroprevalence of SARSCoV-2 in Utsunomiya City, Greater Tokyo, after the first pandemic in 2020. Journal of General and Family Medicine. 2020;n/a(n/a).

19. Petersen MS, Strøm M, Christiansen DH, Fjallsbak JP, Eliasen EH, Johansen M, et al. Seroprevalence of SARS-CoV-2-Specific Antibodies, Faroe Islands. Emerg Infect Dis. 2020; 26(11).

20. Pollán M, Pérez-Gómez B, Pastor-Barriuso R, Oteo J, Hernán MA, Pérez-Olmeda M, et al. Prevalence of SARS-CoV-2 in Spain (ENE-COVID): a nationwide, population-based seroepidemiological study. The Lancet. 2020. https://doi.org/10.1016/S0140-6736(20)31483-5 PMID: 32645347

21. Roxhed N, Bendes A, Dale M, Mattsson C, Hanke L, Dodig-Crnkovic T, et al. A translational multiplex serology approach to profile the prevalence of anti-SARS-CoV-2 antibodies in home-sampled blood. medRxiv; 2020.

22. Shakiba M, Nazemipour M, Salari A, Mehrabian F, Nazari SSH, Rezvani SM, et al. Seroprevalence of SARS-CoV-2 in Guilan Province, Iran, April 2020. Emerg Infect Dis. 2021; 27(2):636-8. https://doi.org/ 10.3201/eid2702.201960 PMID: 33349310

23. Silveira MF, Barros AJD, Horta BL, Pellanda LC, Victora GD, Dellagostin OA, et al. Population-based surveys of antibodies against SARS-CoV-2 in Southern Brazil. Nature Medicine. 2020; 26(8):1196-9. https://doi.org/10.1038/s41591-020-0992-3 PMID: 32641783

24. Snoeck C, Vaillant M, Abdelrahman T, Satagopam V, Turner J, Beaumont K, et al. Prevalence of SARS-CoV-2 infection in the Luxembourgish population: the CON-VINCE study. medRxiv; 2020. 
25. Sood N, Simon P, Ebner P, Eichner D, Reynolds J, Bendavid E, et al. Seroprevalence of SARS-CoV-2Specific Antibodies Among Adults in Los Angeles County, California, on April 10-11, 2020. JAMA. 2020. https://doi.org/10.1001/jama.2020.8279 PMID: 32421144

26. Streeck H, Schulte B, Kümmerer BM, Richter E, Höller T, Fuhrmann C, et al. Infection fatality rate of SARS-CoV2 in a super-spreading event in Germany. Nat Commun. 2020; 11(1):5829. https://doi.org/ 10.1038/s41467-020-19509-y PMID: 33203887

27. Stringhini S, Wisniak A, Piumatti G, Azman AS, Lauer SA, Baysson H, et al. Seroprevalence of antiSARS-CoV-2 IgG antibodies in Geneva, Switzerland (SEROCoV-POP): a population-based study. The Lancet. 2020. https://doi.org/10.1016/S0140-6736(20)31304-0 PMID: 32534626

28. The Finnish Institute for Health and Welfare. Weekly report of THL serological population study of the coronavirus epidemic. Helsinki, Finland; 2020.

29. The Government of Jersey. SARS-CoV-2: Prevalence of antibodies in Jersey. Jersey, UK; 2020.

30. Weis S, Scherag A, Baier M, Kiehntopf M, Kamradt T, Kolanos S, et al. Antibody response using six different serological assays in a completely PCR-tested community after a coronavirus disease 2019 outbreak-the CoNAN study. Clin Microbiol Infect. 2020.

31. Struyf T, Deeks JJ, Dinnes J, Takwoingi Y, Davenport C, Leeflang MMG, et al. Signs and symptoms to determine if a patient presenting in primary care or hospital outpatient settings has COVID-19 disease. Cochrane Database of Systematic Reviews. 2020(7). https://doi.org/10.1002/14651858.CD013665 PMID: 32633856

32. Byambasuren O, Cardona M, Bell K, Clark J, McLaws M-L, Glasziou P. Estimating the extent of asymptomatic COVID-19 and its potential for community transmission: Systematic review and meta-analysis. Official Journal of the Association of Medical Microbiology and Infectious Disease Canada. 2020; COVID-19:Accepted version, e20200030.

33. Ioannidis J. The infection fatality rate of COVID-19 inferred from seroprevalence data. medRxiv. 2020:2020.05.13.20101253. https://doi.org/10.2471/BLT.20.265892 PMID: 33716331

34. Meyerowitz-Katz G, Merone L. A systematic review and meta-analysis of published research data on COVID-19 infection-fatality rates. medRxiv. 2020:2020.05.03.20089854. https://doi.org/10.1016/j.ijid. 2020.09.1464 PMID: 33007452

35. Havers FP, Reed C, Lim T, Montgomery JM, Klena JD, Hall AJ, et al. Seroprevalence of Antibodies to SARS-CoV-2 in 10 Sites in the United States, March 23-May 12, 2020. JAMA Intern Med. 2020. https:// doi.org/10.1001/jamainternmed.2020.4130 PMID: 32692365

36. Levin AT, Hanage WP, Owusu-Boaitey N, Cochran KB, Walsh SP, Meyerowitz-Katz G. Assessing the age specificity of infection fatality rates for COVID-19: systematic review, meta-analysis, and public policy implications. European Journal of Epidemiology. 2020; 35(12):1123-38. https://doi.org/10.1007/ s10654-020-00698-1 PMID: 33289900

37. Ashby B, Best A. Herd immunity. Current Biology. 2021. https://doi.org/10.1016/j.cub.2021.01.006 PMID: 33621500

38. Nishiura H, Linton NM, Akhmetzhanov AR. Serial interval of novel coronavirus (COVID-19) infections. International Journal of Infectious Diseases. 2020; 93:284-6. https://doi.org/10.1016/j.ijid.2020.02.060 PMID: 32145466

39. Organization. WH. Population-based age-stratified seroepidemiological investigation protocol for coronavirus 2019 (COVID-19) infection 2020 [Available from: https://www. who.int/publications/i/item/WHO2019-nCoV-Seroepidemiology-2020.2.

40. Iwasaki A. What reinfections mean for COVID-19. The Lancet Infectious Diseases. 2020. https://doi. org/10.1016/S1473-3099(20)30783-0 PMID: 33058796

41. Tillett RL, Sevinsky JR, Hartley PD, Kerwin H, Crawford N, Gorzalski A, et al. Genomic evidence for reinfection with SARS-CoV-2: a case study. The Lancet Infectious Diseases. 2020. https://doi.org/10. 1016/S1473-3099(20)30764-7 PMID: 33058797

42. Zhou $P$, Yang $X L$, Wang $X G$, Hu B, Zhang L, Zhang $W$, et al. A pneumonia outbreak associated with a new coronavirus of probable bat origin. Nature. 2020; 579(7798):270-3. https://doi.org/10.1038/ s41586-020-2012-7 PMID: 32015507

43. Lin Q, Zhu L, Ni Z, Meng H, You L. Duration of serum neutralizing antibodies for SARS-CoV-2: Lessons from SARS-CoV infection. J Microbiol Immunol Infect. 2020. https://doi.org/10.1016/j.jmii.2020.03.015 PMID: 32249185

44. Cao WC, Liu W, Zhang PH, Zhang F, Richardus JH. Disappearance of antibodies to SARS-associated coronavirus after recovery. N Engl J Med. 2007; 357(11):1162-3. https://doi.org/10.1056/ NEJMc070348 PMID: 17855683 